KEYWORDS

Employment

Labour market

Manpower needs

Economic liberalization

Business cycles

Data analysis

Mathematical models

Employment statistics

Latin America

Lucas Navarro

Assistant Professor in Economics

ILADES-Universidad Alberto Hurtado,

Chile

- lunavarr@uahurtado.cl
CEPAL REVIEW 99 - DECEMBER 2009

\section{Employment dynamics and crises in Latin America}

\author{
Lucas Navarro
}

$\mathrm{T}$

his study presents dynamic labour demand estimates based on information for 15 Latin American countries in the last three decades. It is found that recessions have a direct negative effect on total and wage employment creation. There is also a positive effect of recessions on employment-output elasticity and a negative one on employment-wage elasticity. These results can be interpreted as meaning that policies aimed at reducing labour costs would be of limited effectiveness in combating unemployment during recessions. On the other hand, policies to stimulate aggregate demand would have a stronger positive effect on labour market performance at times of crisis. In all cases, the effects are greater for wage employment than for total employment. This suggests that the increasing flows of workers towards the informal sector during recessions can mitigate the impact of lower economic growth on total employment. 


\section{I}

\section{Introduction}

This paper studies the dynamics of aggregate employment in Latin America from a macroeconomic perspective on the basis of annual data for the past three decades covering 15 countries of the region. The contraction of the world economy as a result of the current financial crisis has undoubtedly affected developing countries, and those of Latin America in particular. The expectation is therefore of a reduction in the growth rate or even the absolute size of many of the region's economies. In this context, it is particularly important to analyse the effects that the anticipated contraction of economic activity might have on Latin American job markets. Some studies have already begun to report the negative impact of the crisis on the region's labour market. Thus, according to ECLAC/ILO (2009), over a million people joined the ranks of the unemployed in Latin America and the Caribbean between the first quarter of 2008 and the first quarter of 2009.

This analysis is considered important from both a business cycle and a structural point of view. During the 1990s, the region's countries implemented reforms that strongly affected the functioning of their labour markets (Weller, 2000; Peres and Stallings, 2000). These reforms were conducted with a view to promoting competition by liberalizing markets and opening up national economies. According to Rodrik (1997), the greater competition resulting from market opening and increased access to imported inputs has not only had a direct effect on employment, but has increased the responsiveness of employment to changes in macroeconomic variables. Labour markets can be expected to become more volatile in this context, with negative effects on output translating into a larger employment response and better wages than before the reforms. ${ }^{1}$ These impacts may thus have changed the behaviour of employment over cycles.

\footnotetext{
$\square$ Study prepared for the workshop "The labour market institutions' present challenges", Economic Development Division, ECLAC, 13 and 14 April 2009. The author is grateful for the valuable comments of an anonymous referee, Carlos García, Daniel Heymann, Roxana Maurizio, Miguel Torres and Jürgen Weller. Any remaining errors are entirely his own.

1 Working with industrial data for Chile, Colombia and Mexico, however, Fajnzylber and Maloney (2004) do not find that trade liberalization in those countries has increased employment-wage elasticities.
}

According to the traditional theory of the firm, demand for labour depends mainly on the level of activity and labour costs. From an economic cycle perspective, the question arises as to which of the two determinants is most important in a recession like the present one. The answer is important because of its policy implications. In particular, it can reveal the potential relative effectiveness of Keynesian policies to stimulate aggregate demand as compared to policies to reduce labour costs. Thus, if employment-wage elasticity falls during recessions, policies to reduce labour costs will be of only limited effectiveness in a recession like the present one.

Figure 1 presents the simple average of data on annual growth in gross domestic product (GDP), employment and real wages for two years before and after the last year of negative GDP growth in the region's 15 largest countries. ${ }^{2}$ In the chart, time 0 is the last year of the recession. For Argentina, for example, this is 2002, while for Chile it is 1999 . The chart reveals a high positive correlation in the dynamic of the three variables. In other words, both employment and real wages behave similarly to GDP in the years on either side of recessions. This being so, the dynamic of real wages may be related to that of labour productivity, which the chart shows to be procyclical. ${ }^{3}$ It can also be observed that, taking the average for the 15 countries, the dynamics of real wages and GDP were remarkably similar one year before and one year after the last year of recession, with a correlation of 0.85 . It seems reasonable to expect that falling real wages would tend to cushion the fall in employment during a recession and rising real wages to limit its recovery. Again, the large contraction of GDP in the recession would have a negative impact on employment, reversed in the subsequent recovery. It is thus difficult to know from the data alone which of the two factors (real wages or economic activity) is the most important for the dynamic of employment during cycles, and recessions in particular. One objective of this paper will be to use econometric estimates to answer this question.

\footnotetext{
2 Details of the data used are presented in section III of this paper.

3 This is because, as figure 1 shows, changes in GDP are always larger than changes in employment.
} 


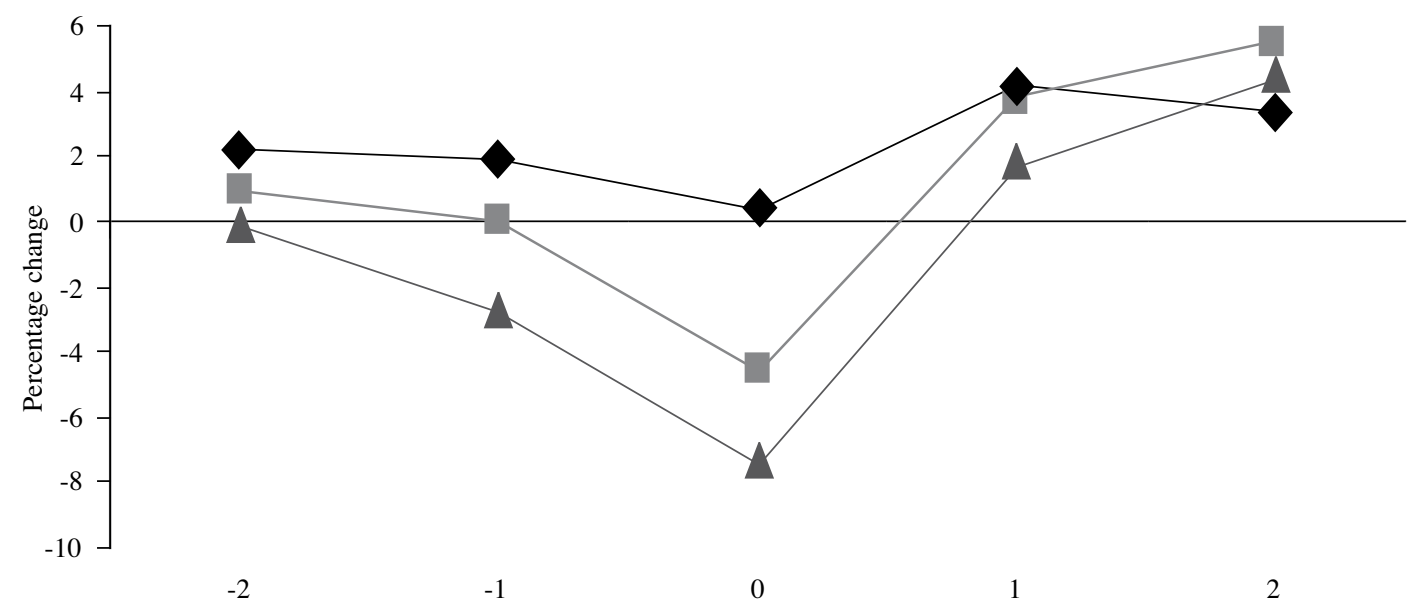

Difference between current year and last year of recession

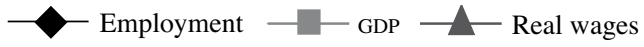

Source: prepared by the author on the basis of data from the Economic Commission for Latin America and the Caribbean (ECLAC).

Accordingly, the first step is to use dynamic panel estimates to calculate traditional labour demand functions. The small size of the sample is a major source of potential bias in the estimates. To mitigate this problem, we use an instrumental variables technique for small samples developed by Hahn, Hausman and Kuersteiner (2007). The results provide signs for the short-term employment-output and employment-wage elasticities that are consistent with international evidence.

Secondly, we analyse the relationship between market opening and employment. The results show real-term exchange-rate depreciations and trade volumes having a positive or nil effect on employment, apparently operating via reductions in real wages.

Lastly, we estimate demand functions for total and wage employment using data from the mid-1990s onward and paying particular attention to the impact of the business cycle. The findings indicate a drop in employment during recessions at every wage level, together with a change in employment-output and employment-wage elasticities. What the estimates in fact show is that changes in wage employment become increasingly responsive to changes in output during recessions, while employment-wage elasticity is lessened. In all cases, the effects on wage employment are greater than the effects on total employment. The reduced responsiveness of total employment to the cycle suggests a growing absorption capacity in the non-wage sector, which consists mainly of informal workers expelled from the formal sector during recessions. Thus, growing employment in the informal sector appears to moderate the aggregate employment impact of lower economic activity.

This paper is structured as follows. The next section briefly presents the theoretical framework for the estimates and discusses the empirical methodology and the specifications to be estimated. Section III then describes the data to be used and Section IV discusses the findings. Lastly, the conclusions are presented (section V). An Appendix is included at the end of the document. 


\section{II}

\section{Dynamic labour demand estimations}

\section{Specification}

Theoretically, the labour demand function can be derived by solving a firm's cost minimization problem. In other words, an aggregate production function for the economy of type $y=A f(k . l)$ is assumed, where $y$ is GDP, $A$ is a Hicks-neutral technology parameter, $k$ is capital and $l$ is the employment level. It is then assumed that the level of employment is the one that minimizes production costs for the economy, subject to the constraint of a given level of output being achieved. One solution to this problem, derived from the first-order condition expressed in logarithms, implies that

$$
\ln (l)=c_{0}+a \ln (w)+b \ln y
$$

where $c_{0}$ is a constant, $a<0$ and $b>0$. Alternatively, (1) could be derived from the price of capital and even from other production factors if we assume a multiple-factor production function. This would consist in considering the first-order conditions for all the production factors and substituting them as appropriate in (1) through $y$. Thus, for example, the first-order condition for capital, appropriately substituted in (1), would imply that $\ln (l)=c_{0}+\operatorname{aln}(w)$ $+b \ln (y)+c \ln (r)$, where $r$ is the cost of capital. Then, both this specification and (1) are correct, although from the econometric standpoint it can be adduced that (1) presents an omitted variables problem, which will be discussed later on. ${ }^{4}$

The four main problems in estimating (1) are aggregation, simultaneity, autocorrelation and measurement errors (Hamermesh, 1993). First, it is recognized that the estimation of aggregate elasticities only reflects the net response of the demand for labour to changes in its determinants, but conceals intrasectoral dynamics. Ideally, one would like to have microdata for each of the countries to reach more reliable estimates of labour demand. Second, it is recognized that wages are not exogenous but are the

\footnotetext{
${ }^{4}$ Many studies use derivations very similar to (1). Some of the most recent include Bruno, Falzoni and Helg (2004) and Castro and Saslavsky (2008).
}

result of the interaction between labour supply and demand. If wages are assumed to be exogenous as in (1), then the implicit assumption is that the supply of labour is perfectly elastic at least within the range of variation of observed wages. Third, the employment and output series present high serial correlation and may be influenced by a strong trend. Lastly, equation (1) has an omitted variables problem, as the effect of the price of other production factors on the demand for labour is not considered..$^{5}$ Limited information is the main constraint when it comes to reducing the impact of these potential problems. Nonetheless, the estimation of the specification of (1) in differences, which will be presented in the following subsection, can help to deal with the drawbacks mentioned. This reduces problems of spurious correlation of series and also simultaneity, since wage variations are less likely to be related to changes in the labour supply in the short term.

A last point to consider is the presence of adjustment costs in employment. Although firms might find it optimal to modify their headcount to a new desired level after a shock, the existence of employee recruitment, training and dismissal costs means that employment will adjust only slowly towards this new level. One way of capturing the partial adjustment of employment is to introduce the lagged dependent variable between the explanatory variables of (1). This specification can be arrived at by introducing the adjustment cost associated with net employment changes $C(d l)$ among the firm's costs and formulating a dynamic problem. When static expectations and quadratic costs are assumed, it transpires that the change in the employment level between two points in time is $d l=\delta\left(\ln \left(l^{*}\right)-\ln (l)\right)$, where $l^{*}$ is the desired long-term employment level and $0 \leq \delta \leq 1 .{ }^{6}$ Thus, the employment adjustment observed is a fraction $\delta$ of the desired adjustment. ${ }^{7}$ Then, setting out from the expression $d l$ above and for

\footnotetext{
${ }^{5}$ After analysing the findings of a great many studies, Hamermesh (1993) concluded that incorporating the prices of other factors in (1) affected the results only slightly.

${ }^{6}$ As in (1), we then have $\ln \left(l^{*}\right)=c_{0}+\operatorname{aln}(w)+b \ln y$.

${ }^{7}$ See Anderson (1993) and Márquez and Pagés (1998) for further details.
} 
an economy $i$ in time $t$, the specification with partial adjustment of employment is

$$
\begin{aligned}
& \ln \left(l_{i t}\right)=\delta c_{0}+\delta a \ln \left(w_{i t}\right)+ \\
& \delta b \ln \left(y_{i t}\right)+(1-\delta) \ln \left(l_{i t-1}\right)
\end{aligned}
$$

where $\delta a$ and $\delta b$ are short-term elasticities, whereas $a$ and $b$ are long-term elasticities. To simplify the presentation, the rest of this study will employ the notation $a^{\prime}=\delta a, b^{\prime}=\delta b$ and $c^{\prime}=1-\delta$.

\section{Estimation technique}

A version of (2) including fixed effects for country $p_{i}$ is

$$
\begin{aligned}
& \ln \left(l_{i t}\right)=p_{i}+a^{\prime} \ln \left(w_{i t}\right)+ \\
& b^{\prime} \ln \left(y_{i t}\right)+c^{\prime} \ln \left(l_{i t-1}\right)+e_{i t}
\end{aligned}
$$

where $i=1 \ldots N$ and $t=1 \ldots T$, with $N$ being the number of countries, $T$ the number of time observations per country and $e_{i t}$ a random error term. The introduction of fixed effects by country in (3) allows us to control for the effect of specific unobservable variables in each country that are not captured by changes in output and wages. Nonetheless, including fixed effects means that the estimation of (3) by ordinary least squares (OLS) is inconsistent. In the first place, the assumption of non-correlation between the fixed effects and the explanatory variables is not acceptable, given that both $l_{i t}$ and $l_{i t-1}$ depend on $p_{i}$, which is invariant in time. One way of addressing this problem is to express (3) in differences, as follows:

$$
\begin{aligned}
& d \ln \left(l_{i t}\right)=a^{\prime} d \ln \left(w_{i t}\right)+ \\
& b^{\prime} d \ln \left(y_{i t}\right)+c^{\prime} d \operatorname{dn}\left(l_{i t-1}\right)+e_{i t}
\end{aligned}
$$

where $d \ln \left(x_{i t}\right)=\ln \left(x_{i t}\right)-\ln \left(x_{i t-1}\right)$ for $x=l, w, y$. The problem that now arises is that differentiating (3) induces a correlation between the lagged dependent variable and the error term. Given that specification (4) comes from a specification in levels, the lagged dependent variable $d \ln \left(l_{i t-1}\right)$ contains part of $e_{i t}$ by construction, since the two elements are correlated. This is because both $d \ln \left(l_{i t}\right)$ and $d \ln \left(l_{i t-1}\right)$ include $\ln \left(l_{i t-1}\right)$. In consequence, $d \ln \left(l_{i t-1}\right)$ is endogenous in (4) and as Bond (2002) suggests, the OLS estimation is inconsistent. To solve this problem, many studies suggest instrumenting $d \ln \left(l_{i t-1}\right)$. One of the techniques most used for this purpose is that of Arellano and Bond (1991), which consists in instrumenting the lagged dependent variable within the framework of the generalized method of moments (GMM) ${ }^{8}$ The problem with this technique is that it is only applicable to large samples and for cases where $N>T$, a condition that is not met with the data in this study. Then, using the Arellano and Bond (1991) technique in small samples would also produce inconsistent and inefficient estimators. This seems to be a particular problem for series in levels where there is high persistence (such as the employment series), and the smaller the sample size and the larger the number of instruments used (among other factors), the worse it becomes. Hahn, Hausman and Kuersteiner (2007) propose a technique for dynamic panels and small samples which, as they demonstrate, minimizes the use of instruments while yielding $c$ ' estimators with better properties in terms of accuracy and the reduction of biases. This technique is also a GMM variant, but it differs from that of Arellano and Bond (1991) in that it uses far fewer instruments, but optimally, which is particularly beneficial for small samples.

Albeit in different applications, the technique of Hahn, Hausman and Kuersteiner (2007) has been used in many studies, such as Brock and Franken (2003), Alfaro and others (2004) and Huang and Ritter (2009). The algorithm consists in estimating the coefficient of the lagged dependent variable $\left(c^{\prime}\right)$ in an initial stage on the basis of a regression of the remainders of two earlier regressions, which are used as instruments. In fact, Hahn, Hausman and Kuersteiner (2007) suggest the remainders from (3) as valid instruments. In the first instance, all the variables are expressed as deviations from the mean. In this way, the model comes to be expressed in multiperiod differences instead of first differences alone, and the fixed effects are removed. In other words, any variable $x_{i t}$ is expressed as $d d \ln \left(x_{i t}\right)$ $=\ln \left(x_{i t}\right)-\operatorname{mean}\left(\ln \left(x_{i t}\right)\right)$. The first remainder is obtained from a regression between the dependent variable and the independent variables, i.e.

$$
\operatorname{res}^{1}{ }_{i t}=\operatorname{ddln}\left(l_{i t}\right)-a^{1^{*}} d d \ln \left(w_{i t}\right)-b^{1^{*}} d d \ln \left(y_{i t}\right)
$$

where $a^{1^{*}}$ and $b^{1^{*}}$ are estimated coefficients. The second remainder $\operatorname{res}^{2}{ }_{i t}$ comes from the same regression as before, but with all the variables lagged one period. From the coefficient of the regression between res $^{1}{ }_{i t}$ and $r e s^{2}{ }_{i t}$ we can obtain an estimator $c^{, * 9}$ to calculate

\footnotetext{
${ }^{8}$ See, for example, Vergara (2005) for an application of Arellano and Bond (1991) in employment studies for Chile.

${ }^{9} \mathrm{~A}$ bias correction such as $c^{* *}=c^{*}(T+1) / T+1 / T$ must be applied to the coefficient of regression between the remainders $c^{*}$.
} 
the variable $z_{i t}=d d \ln \left(l_{i t}\right)-c^{\prime *} d d \ln \left(l_{i t-1}\right)$. Lastly, the estimators for the rest of the coefficients, such as $a^{\prime}$ and $b^{\prime}$ in (3), are obtained from the regression of $z_{i t}$ in the independent variables, i.e.

$$
z_{i t}=a^{\prime} d d \ln \left(w_{i t}\right)+b^{\prime} d d \ln \left(y_{i t}\right)+e_{i t}
$$

Although the advisability of using the Hahn, Hausman and Kuersteiner (2007) technique is emphasized, section IV will also present the results of estimating (4) by OLS.

\section{Trade and employment}

We shall extend specification (4) in two ways. First we shall consider the impact of market opening, measured as the sum of exports plus imports as a percentage of GDP (open), and also of the real exchange rate (RER). It can be assumed that these two variables will affect (1) via a change in the technology parameter $A$ of the production function (Castro and Saslavsky, 2008), or alternatively that exposure to globalization is a variable that enters into the production function (Bruno, Falzoni and Helg, 2004). Another hypothesis suggested later is that these variables could enter (1), indirectly affecting $w_{i t}$. Then we will be able to estimate the following equation:

$$
\begin{aligned}
& d \ln \left(l_{i t}\right)=a^{\prime} d \operatorname{dn}\left(w_{i t}\right)+b^{\prime} d \ln \left(y_{i t}\right)+ \\
& c^{\prime} d \operatorname{dn}\left(l_{i t-1}\right)+d^{\prime} d \operatorname{dn}\left(\operatorname{trade}_{i t}\right)+e_{i t}
\end{aligned}
$$

where trade $=$ open, RER. We shall not include open and $R E R$ in the same estimation because of their potentially high correlation, which could skew the estimates for other parameters. Specification (5) can even present the problem of high correlation between $d \ln \left(w_{i t}\right)$ and the trade variables, which would also create a problem of multicolinearity whose main drawback would be to increase the standard error of the coefficients estimated. This is a particular problem in the case of small samples like those used in this study.

The empirical evidence for the impact of market opening on employment in Latin America is not conclusive (IDB, 2003). Márquez and Pagés (1998), Peres and Stalling (2000) and Weller (2000) have found that market opening affects aggregate employment negatively (albeit variably) while real-term currency depreciation has a positive effect. Haltiwanger and others (2004), meanwhile, have found a positive relationship between net job creation and real-term currency appreciation. Lastly, Galindo, Izquierdo and Montero (2007), working with disaggregated industrial data, have observed that real-term depreciation tends to raise employment in industries with low levels of dollar borrowings and reduce it in industries with heavy foreign currency borrowings. ${ }^{10}$

\section{Cycles and employment}

Another useful extension to (4) is one that reflects the differential impact the economic cycle might have on the demand for labour. For this, the following equation will be estimated:

$$
\begin{aligned}
& d \operatorname{dn}\left(l_{i t}\right)=\left[a^{\prime} d \ln \left(w_{i t}\right)+b^{\prime} d \ln \left(y_{i t}\right)+\right. \\
& \left.c^{\prime} d \operatorname{dn}\left(l_{i t-1}\right)\right]\left[1+f^{\prime} R E C_{i t}\right]+g^{\prime} R E C_{i t}+e_{i t}
\end{aligned}
$$

where $R E C$ is a dummy variable taken from Gutiérrez (2007) for a situation in which the country is in an output slowdown phase. Also considered will be an alternative definition of $R E C$ as a dummy taking the value 1 if GDP growth is negative. As can be seen, specification (6) allows not only a change of position in the aggregate labour demand curve during recessions but also alterations in the short-term elasticities of employment and output. Thus, positive values for $b^{\prime} f^{\prime}$ ' and $a^{\prime} f^{\prime}$ ' will indicate, respectively, an increase in the absolute value of employment-output elasticity and a reduction in employment-wage elasticity during recessions. Then, short-term employment-wage and employment-output elasticities at times of recession are equivalent to $a^{\prime}\left(1+f^{\prime}\right)$ and $b^{\prime}\left(1+f^{\prime}\right)$, respectively.

To capture a better lag structure in (4), (5) and (6), while recognizing the constraint on the number of observations, the wage changes, real exchange-rate and trade volume variables are calculated as a simple average of observations between $t, t-1$ and $t-2$ (the last three years).

\footnotetext{
10 This observation is consistent with Cavallo and others (2004) in their analysis of the repercussions of exchange-rate shocks on economic activity.
} 


\section{III}

\section{Data}

Given the importance of employment information to this study, it needs to be stressed that long, reliable series of aggregate employment figures are not easy to come by for the countries of Latin America and the Caribbean. This study uses employment data obtained in two different ways. First, there are aggregate employment series from household surveys in six countries for the 1985-2008 period. These data are a revised and updated version of those used in table IV.1 of Weller (2000). The countries concerned are Argentina, Brazil, Chile, Colombia, Costa Rica and Mexico. Second, aggregate employment series were estimated for 15 countries covering the 1980-2007 period and using information from the ECLAC Database on Social Statistics and Indicators (BADEINSO) relating to urban unemployment rates $(u)$ and estimates of the economically active population (EAP) from the International Labour Organization (ILO). Then, for each observation, employment $l_{i t}$ is obtained as $l_{i t}=\left(1-u_{i t}\right) E A P_{i t}$. The rest of the information used is from ECLAC databases. The extended dataset (covering 15 countries) presents some observations of unavailable data.
There are thus two panels, a balanced panel of 132 observations (six countries, 22 years) and an unbalanced one of 365 observations for 15 countries and 26 points in time. To facilitate the exposition, the terms G6 and G15 will refer to the first and second panel, respectively. The Appendix presents the descriptive statistics for each country in the two panels of the main variables used.

Table 1 presents the correlations between the variables of interest in this study. The correlation analysis, while it does not yield information about causality, does give an idea of the relationship between the trends of the variables. It should also be noted that these are unconditional pair correlations, i.e., they are not controlled for the dynamic of other variables, as will be done in the following section.

In all the tables in this study, $d l x$ represents the difference of logarithms (percentage change) of $x$ $=l, y, w$, open, RER, where $l$ represents aggregate employment and $y$ output. The variables $w$, open and $R E R$ are the averages of real wages, trade volumes as a percentage of GDP and the real exchange rate (RER), respectively, over the last three years.

TABLE 1

Correlation matrix

(Variables in differences)

\begin{tabular}{|c|c|c|c|c|c|}
\hline & dll & $d l y$ & $d l w 3$ & dlopen 3 & dlrer3 \\
\hline \multicolumn{6}{|c|}{ G6 panel (1985-2008) } \\
\hline$d l l$ & 1 & & & & \\
\hline$d l y$ & $0.3830^{\mathrm{a}}$ & 1 & & & \\
\hline$d l w 3$ & -0.0108 & $0.3373^{\mathrm{a}}$ & 1 & & \\
\hline dlopen3 & 0.0030 & -0.1351 & $-0.3747^{\mathrm{a}}$ & 1 & \\
\hline dlrer3 & 0.1396 & $-0.2744^{\mathrm{a}}$ & $-0.2328^{\mathrm{a}}$ & $0.5231^{\mathrm{a}}$ & 1 \\
\hline \multicolumn{6}{|c|}{ G15 panel (1980-2007) } \\
\hline$d l l$ & 1 & & & & \\
\hline$d l y$ & $0.4749^{\mathrm{a}}$ & 1 & & & \\
\hline$d l w 3$ & -0.0151 & $0.2711^{\mathrm{a}}$ & 1 & & \\
\hline dlopen3 & 0.0318 & 0.0533 & $-0.2216^{\mathrm{a}}$ & 1 & \\
\hline dlrer3 & 0.0473 & -0.0585 & $0.1138^{\mathrm{b}}$ & $0.5012^{\mathrm{a}}$ & 1 \\
\hline
\end{tabular}

Source: prepared by the author.

${ }^{\mathrm{a}}$ and ${ }^{\mathrm{b}}$ indicate statistical significance at $1 \%$ and $5 \%$, respectively. 
As can be seen, there is a positive and statistically significant unconditional correlation for both panels between changes in employment and changes in GDP. The correlation of employment growth with the other variables is not statistically significant enough to be analysed. Finding zero correlation between wages and employment at this stage of the analysis does not necessarily mean there is no relationship between the variables, as will be seen in the following section.

Meanwhile, the positive and statistically significant correlation between output and real wages in differences can be put down to the fact that the wage dynamic partly reflects increases in labour productivity.

The findings in table 1 also indicate a weak negative correlation for both panels between output growth and real depreciation that is statistically significant in the first panel. Although real depreciation benefits export sectors, it makes imports of goods and inputs more expensive and also increases the value of foreigncurrency debts, with a negative impact on economic activity. These last factors seem to dominate the $d l y$-dltcr correlation in the table. As was noted earlier, these correlations do not capture the effect of other variables that may affect the variables analysed. Thus, for example, this negative correlation between real depreciation and growth may be influenced by major devaluations and recessions like those of Mexico in 1994 and Argentina in 2002. ${ }^{11}$

For both samples, and at statistically acceptable confidence levels, a negative correlation can also be observed between differences in real wages and the volume of trade. Although the correlation analysis does

\section{IV}

\section{Results}

Table 2 summarizes the results of estimating (4) using OLS and the Hahn, Hausman and Kuersteiner technique, denoted as HHK, for the two samples mentioned above. The results differ between the two panels but are fairly similar within them for both estimations. Nonetheless, there is a higher coefficient, statistically significant at $1 \%$, for the lagged dependent variable

\footnotetext{
${ }^{11}$ See Agénor and Montiel (1996) for a review of the literature on the effects of real depreciations on economic activity.
}

not yield information about causality, these findings can be interpreted both by the greater competitive pressure on real wages from a larger flow of imports and by the effect on exports of more competitive real wages, as analysed later on.

Where table 1 is concerned, lastly, we can see a statistically significant relationship between changes in real wages and changes in the RER that is negative in the sample of 6 countries, although positive for the larger sample. Both theoretically and empirically, the relationship between real wages and the RER is inconclusive (Campa and Goldberg, 2001; Goldberg and Tracy, 2003). From a microeconomic standpoint, a real-term depreciation can stimulate local output and demand for labour and thus have a positive effect on real wages. On the other hand, by increasing the cost of imported inputs that may complement labour, a real-term depreciation can have a negative effect on wages and the demand for labour. ${ }^{12}$

Where the data presented here are concerned, this correlation may capture, first, a linkage between inflation and real-term currency appreciation in cases where wages are not perfectly indexed to inflation and, as demonstrated in the literature, the law of exchange-rate purchasing power parity (PPP) does not operate. Again, a negative correlation may be explained by the effect of real productivity increases that can translate into higher real wages and an appreciation of the RER. The table 1 results seem to suggest that the second explanation predominates for the sample of 6 countries and the first for the larger sample.

in the HHK estimates with both panels. This reflects the better properties of the estimators obtained with this technique. For this reason, only the results of the HHK estimates will be included in the remaining tables of this study.

\footnotetext{
${ }^{12}$ Furthermore, Mishra and Spilimbergo (2009) consider a positive effect of real exchange-rate depreciation on real wages in countries with a high level of international labour mobility. In this case, depreciation spurs emigration and this can lead to a reduction in the local labour supply and higher real wages.
} 
TABLE 2

OLS and HHK estimates

(Dependent variable: growth in aggregate employment (DLL))

\begin{tabular}{|c|c|c|c|c|}
\hline Estimate & OLS & HHK & OLS & HHK \\
\hline \multirow[t]{2}{*}{$d l y$} & 0.336 & 0.319 & 0.2746 & 0.249 \\
\hline & {$[0.0566]^{\mathrm{a}}$} & {$[0.0608]^{\mathrm{a}}$} & {$[0.0365]^{\mathrm{a}}$} & {$\left[0.0372^{\mathrm{a}}\right.$} \\
\hline \multirow[t]{2}{*}{$d l w$} & -0.118 & -0.113 & -0.0512 & -0.046 \\
\hline & {$[0.0482]^{\mathrm{b}}$} & {$[0.0513]^{\mathrm{a}}$} & {$[0.0148]^{\mathrm{a}}$} & {$[0.0142]^{\mathrm{a}}$} \\
\hline \multirow[t]{2}{*}{$\operatorname{dll}(-1)$} & 0.185 & 0.279 & 0.0797 & 0.292 \\
\hline & {$[0.1084]^{\mathrm{c}}$} & {$[0.0812]^{\mathrm{a}}$} & {$[0.0574]$} & {$[0.0495]^{\mathrm{a}}$} \\
\hline Observations & 132 & 132 & 359 & 359 \\
\hline Countries & 6 & 6 & 15 & 15 \\
\hline $\mathrm{R}$-squared & 0.21 & 0.14 & 0.28 & 0.22 \\
\hline Period & $1985-2008$ & $1985-2008$ & $1980-2007$ & $1980-2007$ \\
\hline \multicolumn{5}{|c|}{ Long-term effects } \\
\hline \multirow[t]{2}{*}{$d l y$} & 0.412 & 0.442 & 0.298 & 0.352 \\
\hline & {$[0.073]^{\mathrm{a}}$} & {$[0.0844]^{\mathrm{a}}$} & {$[0.0373]^{\mathrm{a}}$} & {$[0.0526]^{\mathrm{a}}$} \\
\hline$d l w$ & $\begin{array}{l}-0.145 \\
{[0.0608]^{b}}\end{array}$ & $\begin{array}{l}-0.157 \\
{[0.0071]^{\mathrm{a}}}\end{array}$ & $\begin{array}{l}-0.056 \\
{[0.0160]^{\mathrm{a}}}\end{array}$ & $\begin{array}{l}-0.065 \\
{[0.0201]^{\mathrm{a}}}\end{array}$ \\
\hline
\end{tabular}

Source: prepared by the author.

N.B.: This table reports the results of ordinary least squares (OLS) and Hahn, Hausman and Kuersteiner (HHK) regressions of specification (4), for the G6 (columns 2-3) and G15 (columns 4-5) samples. It also reports the long-term effects derived from the estimates. Robust standard errors are reported in square brackets below each coefficient.

$\mathrm{a}, \mathrm{b}$ and ${ }^{\mathrm{c}}$ indicate statistical significance at $1 \%, 5 \%$ and $10 \%$, respectively.

In the first place, as predicted by theory and in line with the literature, the findings reflect positive and negative employment-output and employment-real wage elasticities, respectively. Thus, for both estimates the coefficients of changes in GDP and wages are always statistically significant. ${ }^{13}$

First, the data in the G6 panel (columns 2 and 3) allow us to situate short-term employment-output elasticity between 0.32 and 0.34 , while employmentwage elasticity varies between -0.11 and -0.12 . The coefficient of the lagged dependent variable presents greater variation between the estimates and is within the range $[0.18,0.28]$. The estimators are statistically significant at acceptable confidence levels. The fact

13 This may seem to contradict the absence of correlation between real wages and employment shown in table 1 , but it does not. The table 2 estimates indicate that for a constant level of output, higher real wages tend to reduce employment. In table 1 there are clearly a range of factors that affect the employment-wage correlation and one of these is in fact the dynamic of output which, as we have seen, relates positively to changes in real wages. that the coefficients of the lagged dependent variable are relatively small means that the long-term effects are only slightly greater than the short-term ones. In fact, short-term impacts account for $80 \%$ of the total effects. Thus, in the case of employment-output elasticity, the average long-term elasticity for the two estimates is 0.33 and 0.43 in the short and long term, respectively. These coefficients are somewhat lower than those reported in Weller (2000), which uses the same database but running up to 1998. Although they are not strictly comparable given that the specification is very slightly different, these results would indicate a tendency for the responsiveness of employment to changes in GDP to diminish over the past 10 years.

Broadly speaking, the results obtained from the sample of 15 countries (columns 4 and 5) are qualitatively similar to those described in the previous paragraph, although the coefficients present markedly lower magnitudes. As can be seen, the coefficient of changes in GDP drops to 0.26 and that of wages to about 0.05 on average. As with the six-country panel 
estimation, we can once again observe larger differences between the two estimations in the coefficient of the lagged dependent variable, although the short- and long-term effects are similar.

What explains the differences in the elasticities obtained with the two panels? Apart from the fact that the time series are slightly different, it is probable that the group of countries included in G6 have a different production and technology structure from the other countries included in the G15 panel. Following Hamermesh (2004), the differences in elasticities may involve radical differences in the composition of output and even in the technology employed in the countries to produce identical products. Indeed, one striking difference between the characteristics of the two samples of countries is that the G15 panel includes economies in which the rural sector is more preponderant and there is a lower percentage of wage employment. Thus, on the basis of the latest data available from CEPALSTAT, appreciable differences can be observed between the countries in the two samples as regards the composition of the labour employed by occupational category and sector of activity, so much so that, taking data from 2003 to 2007 depending on the country, we find that the wage earners and own-account groups represent, respectively, $67.4 \%$ and $24 \%$ for the countries making up the G6 panel and $57.6 \%$ and $33 \%$ for the remaining countries included in the G15 panel. Agricultural sector employment, meanwhile, accounts for $15 \%$ and $25.2 \%$ of the total in the G6 panel countries and the rest of the countries, respectively.

\section{Trade and employment}

Specification (5) incorporates the hypothesis that economic opening processes like those undergone by many of the region's countries over recent decades influence the demand for labour. There is no straightforward theoretical or empirical answer to the question of what impact this process has on employment. ${ }^{14}$

Cuts in real wages are one mechanism through which greater competition can influence employment. If this happened, specification (5) would present a multicolinearity problem. As can be seen in table 1, there is also a high correlation between trade volumes and the real exchange rate. Columns 2 to 5 of table 3 thus present the results of regressions for specification (5), but without including the real wages variable. ${ }^{15}$

\footnotetext{
14 For a discussion see, for example, IDB (2003).

${ }^{15}$ Because the long-term effects will not be analysed, the coefficients
}

Columns 3 and 4 look at the differentiated impact that exports (dlexp) and imports (dlimp) may have on the market opening variable.

In the case of the G6 panel, it transpires that both a deepening of trade and real currency depreciations positively affect net job creation. According to the results of columns 3 and 4, this positive effect of opening on employment is dominated by the positive effect of exports (dlexp) and not imports (dlimp), which would affect employment negatively. Similar (although not always statistically significant) findings derive from the estimates based on sample G15. As can be seen, inclusion of both the market opening variable and the RER does not seem to greatly affect the coefficients that measure the effect of output growth on employment.

Columns 6 to 9 of table 3, meanwhile, display the results of the estimation for (5), including the real wages variable. There it is observed that the HHK estimation in table 2 using G15 data is not very sensitive to the inclusion of external trade variables. Different results are yielded by the estimation using data from six countries (G6 panel). What stands out there is that including all trade variables along with $d l w$ seems to generate problems of colinearity with wages, given that in all cases the wages coefficient becomes statistically indistinguishable from zero. Indeed, as can be seen, even though the real wage affects job creation in estimate (4), the effect becomes statistically insignificant in estimate (5). This suggests that the problem of colinearity is not minor.

This result is not surprising given the discussion in the previous section on the correlations between changes in wages, real exchange rates and market opening. Furthermore, the results of regressions in differences of real wages with trade volume (dlopen) and the real exchange rate (dlrer) are consistent with the table 1 correlations. In other words, the G6 panel data indicate that greater openness (dominated by the export effect) and, to a lesser extent, real exchange-rate depreciations relate negatively to real wages. These estimates are presented in table A3 of the Appendix. These results, together with those in table 3 , suggest that the partial evidence of positive employment effects from market opening could operate via an indirect effect of this process in reducing real wages.

of the lagged dependent variable are not reported. In any event, the coefficients are quite similar to those of table 2 for the hhk model. 
TABLE 3

Employment, market opening and real exchange rates

(Dependent variable: growth in aggregate employment (dll))

\begin{tabular}{|c|c|c|c|c|c|c|c|c|}
\hline & $d l l$ & $d l l$ & $d l l$ & dll & dll & $d l l$ & dll & $d l l$ \\
\hline \multirow[t]{2}{*}{ dlopen } & 0.1044 & & & & 0.0775 & & & \\
\hline & {$[0.0486]^{\mathrm{b}}$} & & & & {$[0.0452]^{\mathrm{c}}$} & & & \\
\hline \multirow[t]{2}{*}{ dlexp } & & 0.1335 & & & & 0.1101 & & \\
\hline & & {$[0.0634]^{\mathrm{b}}$} & & & & {$[0.0672]$} & & \\
\hline \multirow[t]{2}{*}{ dlimp } & & & -0.0995 & & & & -0.09 & \\
\hline & & & {$[0.0324]^{\mathrm{a}}$} & & & & {$[0.0314]^{\mathrm{a}}$} & \\
\hline \multirow[t]{2}{*}{ dlrer } & & & & 0.1014 & & & & 0.0935 \\
\hline & & & & {$[0.0277]^{\mathrm{a}}$} & & & & {$[0.0256]^{\mathrm{a}}$} \\
\hline \multirow[t]{2}{*}{$d l y$} & 0.2853 & 0.3042 & 0.3799 & 0.3561 & 0.3103 & 0.3255 & 0.3984 & 0.375 \\
\hline & {$[0.0578]^{\mathrm{a}}$} & {$[0.0594]^{\mathrm{a}}$} & {$[0.0650]^{\mathrm{a}}$} & {$[0.0654]^{\mathrm{a}}$} & {$[0.0620]^{\mathrm{a}}$} & {$[0.0630]^{\mathrm{a}}$} & {$[0.0653]^{\mathrm{a}}$} & {$[0.0680]^{\mathrm{a}}$} \\
\hline \multirow[t]{2}{*}{$d l w$} & & & & & -0.069 & -0.066 & -0.0715 & -0.0648 \\
\hline & & & & & {$[0.0515]$} & {$[0.0568]$} & {$[0.0502]$} & {$[0.0470]$} \\
\hline Observations & 126 & 126 & 126 & 126 & 126 & 126 & 126 & 126 \\
\hline Countries & 6 & 6 & 6 & 6 & 6 & 6 & 6 & 6 \\
\hline Period & $1985-2008$ & $1985-2008$ & $1985-2008$ & $1985-2008$ & $1985-2008$ & $1985-2008$ & $1985-2008$ & $1985-2008$ \\
\hline R-squared & 0.15 & 0.16 & 0.18 & 0.19 & 0.16 & 0.17 & 0.19 & 0.21 \\
\hline \multirow[t]{2}{*}{ dlopen } & 0.0147 & & & & 0.0017 & & & \\
\hline & {$[0.0148]$} & & & & [0.0159] & & & \\
\hline \multirow[t]{2}{*}{ dlexp } & & 0.0016 & & & & 0.009 & & \\
\hline & & {$[0.0198]$} & & & & {$[0.0206]$} & & \\
\hline \multirow[t]{2}{*}{ dlimp } & & & -0.0423 & & & & -0.0418 & \\
\hline & & & {$[0.0131]^{\mathrm{a}}$} & & & & {$[0.0126]^{\mathrm{a}}$} & \\
\hline \multirow[t]{2}{*}{ dlrer } & & & & 0.0256 & & & & 0.0319 \\
\hline & & & & {$[0.0099]^{\mathrm{b}}$} & & & & {$[0.0108]^{\mathrm{a}}$} \\
\hline \multirow[t]{2}{*}{$d l y$} & 0.2149 & 0.2172 & 0.2481 & 0.2193 & 0.2506 & 0.2504 & 0.2795 & 0.2581 \\
\hline & {$[0.0376]^{\mathrm{a}}$} & {$[0.0384]^{\mathrm{a}}$} & {$[0.0377]^{\mathrm{a}}$} & {$[0.0376]^{\mathrm{a}}$} & {$[0.0378]^{\mathrm{a}}$} & {$[0.0381]^{\mathrm{a}}$} & {$[0.0364]^{\mathrm{a}}$} & {$[0.0372]^{\mathrm{a}}$} \\
\hline \multirow[t]{2}{*}{$d l w$} & & & & & -0.0453 & -0.0462 & -0.0397 & -0.0531 \\
\hline & & & & & {$[0.0155]^{\mathrm{a}}$} & {$[0.0136]^{\mathrm{a}}$} & {$[0.0140]^{\mathrm{a}}$} & {$[0.0127]^{\mathrm{a}}$} \\
\hline Observations & 378 & 378 & 378 & 378 & 359 & 359 & 359 & 359 \\
\hline Countries & 15 & 15 & 15 & 15 & 15 & 15 & 15 & 15 \\
\hline Period & $1980-2007$ & $1980-2007$ & $1980-2007$ & 1980-2007 & 1980-2007 & $1980-2007$ & $1980-2007$ & $1980-2007$ \\
\hline R-squared & 0.18 & 0.18 & 0.21 & 0.19 & 0.22 & 0.22 & 0.26 & 0.25 \\
\hline
\end{tabular}

Source: prepared by the author.

N.B.: This table reports results for regressions of employment with the volume of trade, exports, imports and the real exchange rate in differences and for specification (5) for the G6 and G15 samples, respectively. Robust standard errors are reported in square brackets below each coefficient.

a ${ }^{b}$ and ${ }^{c}$ indicate statistical significance at $1 \%, 5 \%$ and $10 \%$, respectively. 


\section{Cycles and employment}

This subsection presents the results of the estimation of (6) for the eight countries included in Gutiérrez (2007), using wage and total employment series for 1994-2007 and total employment series for 1980-2007. ${ }^{16}$ Unfortunately, there is no wage employment series going further back, and indeed some observations are unavailable for certain of the countries included in the sample.

Specification (6) considers the differential effect of recessions on the demand for employment, which is captured by the $R E C$ dummy. Using annual series for eight countries in the region, Gutiérrez (2007) identifies phases of accelerating and slowing output when the cycle obtained from a Hodrick-Prescott filter for per capita GDP presents three consecutive years of a rising and falling trend, respectively. Periods in which there is no marked tendency are defined as stable. The $R E C$ dummy thus takes the value 1 when the country is in a downturn phase for per capita output. Table A4 of the Appendix presents descriptive statistics for the change in total and wage employment and the REC dummy in the 1994-2007 period under analysis. One problem with this variable is that it does not exclusively capture periods of declining economic activity. This is because, according to the definition of a downturn used in Gutiérrez (2007), the economy could be growing below trend at both positive and negative growth rates. The particular problem for this series is that there are virtually no periods of economic contraction in the countries considered over the time period covered. In longer series it is possible to identify more extended periods of contraction. Accordingly, equation (6) was estimated with the total employment series for the G15 panel, defining a recession as a period in which GDP growth is negative. The results are reported in columns 6 and 7 of table 4 .

Table 4 summarizes the results of the labour demand estimates. ${ }^{17}$ The specifications of columns 2, 4 and 6 come from adding only the $R E C$ dummy to the original specification (4). In the first place, we observe substantially higher employment-output and employment-wage elasticities in the demand for wage employment than in that for total employment. In

\footnotetext{
${ }^{16}$ The total employment data used in this subsection come from the G15 panel. The countries considered are Argentina, Brazil, Chile, Colombia, Costa Rica, Mexico, Peru and Venezuela.

17 The coefficients of the lagged dependent variable were not reported, being very similar to those of the hhk model in table 2 .
}

the second place, the $R E C$ coefficient is negative in all cases, although not statistically significant.

Meanwhile, columns 3, 5 and 7 show the results of the estimation of (6) for wage and total employment, as applicable. The positive and in some cases statistically significant signs for dlyREC and $d l w R E C$ indicate an increase in absolute employment-output elasticity and a reduction in employment-wage elasticity during downturns.

The final rows of table 4 report the coefficients for the total effects of changes in output and real wages on employment during recessions, obtained by estimating specification (6). These coefficients represent short-term employment-output and employment-wage elasticities at times of recession and are equivalent in equation (6) to $a^{\prime}\left(1+f^{\prime}\right)$ and $b^{\prime}\left(1+f^{\prime}\right)$, respectively. In all cases, the coefficients of $d l y+d l y R E C$ are greater than those of $d l y$ and are statistically significant.

In the case of wage employment, employmentoutput elasticity rises from 0.3 at times of stability and rising growth to almost 0.75 during recessions. Total employment also becomes considerably more responsive to changes in GDP during recessions, albeit not to the same extent (columns 5 and 7).

Meanwhile, the wage coefficient in the equation with wage employment falls from -0.22 at times of stability and faster GDP growth to -0.03 in recessions. There also seems to be a tendency for wages to become detached from total employment during recessions. Thus, in the estimation in column 7 of table 4 , where negative output growth is used as a measure of recession, the wage coefficient goes from -0.07 in periods of stability and strong growth to -0.04 in recessions.

A first explanation for these results is that companies' demand for labour is constrained by lower demand for their products in recessions and that falling wages are not enough to boost employment. In this context, expectations must also be an important factor. Thus, for example, even when recruitment subsidies exist at times of recession, firms will not necessarily increase employment if they do not expect demand for their products to recover.

The table 4 results can also be explained using two of the traditional Marshall rules for derived factor demand (Hamermesh, 1993): (i) first, if a negative demand shock involves redundancies, it is to be expected that labour costs will fall as a share of firms' total production costs and therefore that these will ultimately respond with few changes in wages. In this context, demand for labour would become more 
TABLE 4

Employment and cycles

(Dependent variable: growth in wage employment (dllwage) and aggregate employment (dll))

\begin{tabular}{|c|c|c|c|c|c|c|}
\hline & dllwage & dllwage & $d l l$ & dll & $d l l$ & $d l l$ \\
\hline \multirow[t]{2}{*}{$d l y$} & 0.411 & 0.305 & 0.225 & 0.194 & 0.201 & 0.175 \\
\hline & {$[0.0621]^{\mathrm{a}}$} & {$[0.0596]^{\mathrm{a}}$} & {$[0.0386]^{\mathrm{a}}$} & {$[0.0366]^{\mathrm{a}}$} & {$[0.0529]^{\mathrm{a}}$} & {$[0.0427]^{\mathrm{a}}$} \\
\hline \multirow[t]{2}{*}{$d l w$} & -0.178 & -0.225 & -0.079 & -0.122 & -0.047 & -0.070 \\
\hline & {$[0.0937]^{\mathrm{c}}$} & {$[0.0994]^{\mathrm{b}}$} & {$[0.0459]^{\mathrm{c}}$} & {$[0.0503]^{\mathrm{b}}$} & {$[0.0135]^{\mathrm{a}}$} & {$[0.0243]^{\mathrm{a}}$} \\
\hline \multirow[t]{2}{*}{$R E C$} & -0.007 & -0.021 & -0.002 & -0.007 & -0.008 & -0.007 \\
\hline & {$[0.0070]$} & {$[0.0063]^{\mathrm{a}}$} & [0.0039] & [0.0043] & {$[0.0047]$} & {$[0.0051]$} \\
\hline \multirow[t]{2}{*}{ dlyREC } & & 0.442 & & 0.133 & & 0.064 \\
\hline & & {$[0.1292]^{\mathrm{a}}$} & & {$[0.0730]^{\mathrm{c}}$} & & {$[0.1325]$} \\
\hline \multirow[t]{2}{*}{$d l w R E C$} & & 0.193 & & 0.134 & & 0.031 \\
\hline & & {$[0.1507]$} & & {$[0.0748]^{\mathrm{c}}$} & & {$[0.0325]$} \\
\hline Observations & 91 & 91 & 96 & 96 & 359 & 359 \\
\hline Countries & 8 & 8 & 8 & 8 & 15 & 15 \\
\hline Period & 1994-2007 & 1994-2007 & 1994-2007 & 1994-2007 & $1980-2007$ & $1980-2007$ \\
\hline R-squared & 0.33 & 0.4 & 0.25 & 0.28 & 0.23 & 0.23 \\
\hline \multicolumn{7}{|l|}{ Total effects } \\
\hline \multirow[t]{2}{*}{$d l y+d l y R E C$} & & 0.747 & & 0.327 & & 0.238 \\
\hline & & {$[0.1175]^{\mathrm{a}}$} & & {$[0.0654]^{\mathrm{a}}$} & & {$[0.1250]^{\mathrm{c}}$} \\
\hline$d l w+d l w R E C$ & & $\begin{array}{l}-0.032 \\
{[0.1135]}\end{array}$ & & $\begin{array}{l}0.012 \\
{[0.05636]}\end{array}$ & & $\begin{array}{l}-0.039 \\
{[0.0194]^{b}}\end{array}$ \\
\hline
\end{tabular}

Source: prepared by the author.

N.B.: Columns 2 to 5 report the results for regressions of specification (4). The sample encompasses the eight countries included in Gutiérrez (2007), whence the REC variable is obtained. Results are presented for wage employment (columns 2-3) and total employment (columns 4-5). Columns 6 and 7 present the results for 15 countries, taking a decline in GDP as a measure of recession. Wage employment data are only available for the 1994-2007 period. The total effects $d l w$ and $d l y$ deriving from the interaction with $R E C$ are also reported. Robust standard errors are reported in square brackets below each coefficient.

${ }^{\mathrm{a}},{ }^{\mathrm{b}}$ and ${ }^{\mathrm{c}}$ indicate statistical significance at $1 \%, 5 \%$ and $10 \%$, respectively.

sensitive to demand for firms' products than to wages; (ii) furthermore, if the demand elasticity of output falls in recessions, firms will have fewer incentives to cut prices and this will feed through into lower employment-wage elasticity. In other words, during recessions the impact of falling wages on prices would not translate into higher demand for their products. This hypothesis could be supported by evidence from a large literature showing that the price elasticity of demand for output is procyclical. ${ }^{18}$

\footnotetext{
${ }^{18}$ The procyclicality of output demand elasticity can be explained by an imperfect competition argument. With imperfect competition, firms produce below socially optimum levels. The volatility of output during cycles means that this inefficiency is countercyclical and the market power of firms can thus be expected to increase in recessions when production falls. Thinking along these lines can be found in Blanchard and Kiyotaki (1987).
}

This would be consistent with lower employmentwage elasticity in recessions. ${ }^{19}$

Lastly, the observation in all cases of higher wage employment elasticities in relation to total employment suggests a change in the composition of employment during recessions. The fact that wage employment is destroyed to a far greater extent than total employment when economic growth diminishes appears to indicate that informal employment behaves countercyclically, helping to reduce the negative impact of recessions on total employment. ${ }^{20}$

\footnotetext{
${ }^{19}$ See, for example, Edmond and Veldkamp (2008). In this literature, the procyclicality of the price elasticity of demand for output derives from the countercyclicality of profit margins, defined as the ratio between marginal costs and prices.

20 This result can be found online in Loayza and Rigolini (2006), who observe countercyclical behaviour in formal employment in
} 


\section{V}

\section{Conclusions}

This study presents dynamic labour demand estimates based on data for 15 Latin American countries over the 1980-2008 period.

The results yield employment-output and employment-wage elasticities with signs that are consistent with theory and the international empirical evidence. The magnitudes of the elasticities are somewhat smaller than the average values reported by Hamermesh (1993) for a large number of studies. One of the reasons for this divergence is probably that estimates reflect net aggregate effects. There is thus a loss of information on adjustment differences between and within sectors.

In any event, and despite the limitations of using aggregate data, there are some results that may be of relevance to the region's current economic context. In

a sample of industrialized and developing countries. Using data from Brazil and Mexico, Maloney and Bosch (2008) find that the percentage of formal employment is countercyclical, although shifts from formal to informal employment are not countercyclical but procyclical. particular, an asymmetry is observed in the response of employment to its main determinants with respect to the economic cycle. Indeed, recessions not only bring downward shifts in the demand for labour, but also changes in the responsiveness of employment to economic growth and to changes in real wages.

The results predict an increased employmentoutput elasticity and a decreased employment-wage elasticity during the output slowdown and contraction phases. This suggests that policies to reduce labour costs would have a limited impact in reducing unemployment during recessions. Conversely, the results suggest that the positive employment impact of policies to stimulate aggregate demand would be enhanced at times of crisis.

Lastly, it is found that the effects described in the previous paragraph are concentrated in wage employment rather than total employment. This can be interpreted as a reallocation of surplus wage workers to the informal sector of the economy during recessions. These employment flows into the informal sector seem to reduce the negative impact of downturns on total employment.

APPENDIX

TABLE A1

Six countries: descriptive statistics, G6 panel (1985-2008)

\begin{tabular}{lccccc}
\hline \multicolumn{1}{c}{ Country } & $d l l$ & $d l y$ & $d l w$ & dlrer & dlopen \\
\hline Argentina & 0.020 & 0.033 & 0.013 & 0.018 & 0.050 \\
\multirow{3}{*}{ Brazil } & 0.026 & 0.060 & 0.078 & 0.147 & 0.075 \\
& 0.021 & 0.027 & -0.003 & -0.009 & 0.037 \\
Chile & 0.021 & 0.026 & 0.058 & 0.094 & 0.058 \\
& 0.027 & 0.056 & 0.025 & 0.003 & 0.021 \\
Colombia & 0.017 & 0.027 & 0.012 & 0.056 & 0.028 \\
Costa Rica & 0.034 & 0.039 & 0.011 & 0.010 & 0.016 \\
& 0.039 & 0.025 & 0.014 & 0.091 & 0.019 \\
Mexico & 0.037 & 0.051 & 0.007 & 0.009 & 0.031 \\
Average & 0.030 & 0.024 & 0.029 & 0.044 & 0.030 \\
& 0.018 & 0.027 & 0.011 & -0.006 & 0.038 \\
& 0.027 & 0.030 & 0.042 & 0.096 & 0.064 \\
\end{tabular}

Source: prepared by the author.

N.B.: For each country, the first row shows the mean of each variable and the second its standard deviation. 
TABLE A2

Fifteen countries: descriptive statistics, G15 panel (1980-2007)

\begin{tabular}{|c|c|c|c|c|c|}
\hline Country & $d l l$ & $d l y$ & $d l w$ & dlrer & dlopen \\
\hline \multirow[t]{2}{*}{ Argentina } & 0.022 & 0.02 & -0.004 & 0.046 & 0.038 \\
\hline & 0.021 & 0.062 & 0.055 & 0.162 & 0.083 \\
\hline \multirow[t]{2}{*}{ Bolivia (Pl. St. of) } & 0.03 & 0.023 & 0.034 & 0.03 & 0.017 \\
\hline & 0.022 & 0.028 & 0.052 & 0.088 & 0.054 \\
\hline \multirow[t]{2}{*}{ Brazil } & 0.025 & 0.024 & 0 & 0.009 & 0.01 \\
\hline & 0.019 & 0.032 & 0.043 & 0.1 & 0.075 \\
\hline \multirow[t]{2}{*}{ Chile } & 0.023 & 0.045 & 0.019 & 0.02 & 0.016 \\
\hline & 0.035 & 0.049 & 0.029 & 0.085 & 0.049 \\
\hline \multirow[t]{2}{*}{ Colombia } & 0.036 & 0.035 & 0.019 & 0.017 & 0.007 \\
\hline & 0.018 & 0.023 & 0.015 & 0.085 & 0.048 \\
\hline \multirow[t]{2}{*}{ Costa Rica } & 0.036 & 0.041 & 0.003 & 0.02 & 0.018 \\
\hline & 0.02 & 0.036 & 0.044 & 0.128 & 0.087 \\
\hline \multirow[t]{2}{*}{ Ecuador } & 0.036 & 0.026 & 0.007 & 0.024 & 0.01 \\
\hline & 0.025 & 0.035 & 0.069 & 0.089 & 0.061 \\
\hline \multirow[t]{2}{*}{ Guatemala } & 0.02 & 0.028 & 0.011 & 0.002 & 0.013 \\
\hline & 0.025 & 0.023 & 0.088 & 0.071 & 0.071 \\
\hline \multirow[t]{2}{*}{ Mexico } & 0.029 & 0.026 & -0.001 & 0.002 & 0.029 \\
\hline & 0.014 & 0.034 & 0.051 & 0.084 & 0.067 \\
\hline \multirow[t]{2}{*}{ Nicaragua } & 0.029 & 0.016 & -0.046 & -0.037 & 0.012 \\
\hline & 0.023 & 0.041 & 0.214 & 0.232 & 0.133 \\
\hline \multirow[t]{2}{*}{ Panama } & 0.033 & 0.038 & 0.004 & 0.02 & 0.018 \\
\hline & 0.024 & 0.05 & 0.022 & 0.025 & 0.152 \\
\hline \multirow[t]{2}{*}{ Paraguay } & 0.036 & 0.026 & 0.004 & 0.034 & 0.043 \\
\hline & 0.025 & 0.029 & 0.031 & 0.097 & 0.102 \\
\hline \multirow[t]{2}{*}{ Peru } & 0.034 & 0.024 & -0.038 & -0.03 & 0.003 \\
\hline & 0.016 & 0.062 & 0.096 & 0.084 & 0.072 \\
\hline \multirow[t]{2}{*}{ Uruguay } & 0.016 & 0.019 & -0.005 & 0.022 & 0.019 \\
\hline & 0.021 & 0.055 & 0.047 & 0.102 & 0.06 \\
\hline \multirow[t]{2}{*}{ Venezuela (Bol. Rep. of) } & 0.037 & 0.021 & -0.051 & 0.01 & -0.001 \\
\hline & 0.021 & 0.064 & 0.059 & 0.096 & 0.06 \\
\hline Average & $\begin{array}{l}0.03 \\
0.023\end{array}$ & $\begin{array}{l}0.027 \\
0.044\end{array}$ & $\begin{array}{r}-0.003 \\
0.079\end{array}$ & $\begin{array}{l}0.013 \\
0.111\end{array}$ & $\begin{array}{l}0.017 \\
0.083\end{array}$ \\
\hline
\end{tabular}

Source: prepared by the author.

N.B.: For each country, the first row shows the mean of each variable and the second its standard deviation. 
TABLE A3

Market opening, real exchange rate and real wages

(Dependent variable: growth in real wages (dlw))

\begin{tabular}{|c|c|c|c|c|c|c|c|c|}
\hline & $d l w$ & $d l w$ & $d l w$ & $d l w$ & $d l w$ & $d l w$ & $d l w$ & $d l w$ \\
\hline \multirow[t]{2}{*}{ dlopen } & -0.343 & & & & -0.225 & & & \\
\hline & {$[0.0603]^{\mathrm{a}}$} & & & & {$[0.0656]^{\mathrm{a}}$} & & & \\
\hline \multirow[t]{2}{*}{ dlexp } & & -0.364 & & & & 0.003 & & \\
\hline & & {$[0.1217]^{\mathrm{b}}$} & & & & {$[0.1728]$} & & \\
\hline \multirow[t]{2}{*}{ dlimp } & & & 0.180 & & & & 0.203 & \\
\hline & & & {$[0.0419]^{\mathrm{a}}$} & & & & {$[0.0452]^{\mathrm{a}}$} & \\
\hline \multirow[t]{2}{*}{ dlrer } & & & & -0.154 & & & & 0.058 \\
\hline & & & & {$[0.0262]^{\mathrm{a}}$} & & & & [0.1569] \\
\hline Observations & 126 & 126 & 126 & 126 & 382 & 382 & 382 & 382 \\
\hline Countries & 6 & 6 & 6 & 6 & 15 & 15 & 15 & 15 \\
\hline $\mathrm{R}$-squared & 0.17 & 0.14 & 0.1 & 0.1 & 0.06 & 0 & 0.05 & 0.01 \\
\hline Period & 1985-2008 & $1985-2008$ & 1985-2008 & 1985-2008 & $1980-2007$ & $1980-2007$ & $1980-2007$ & $1980-2007$ \\
\hline
\end{tabular}

Source: prepared by the author.

N.B.: This table reports the results for regressions of real wages with the volume of trade, exports, imports and the real exchange rate (rer) in differences, for the G6 (columns 2-3) and G15 (columns 4-5) samples. Robust standard errors are reported in square brackets below each coefficient.

$\mathrm{a}$ and ${ }^{\mathrm{b}}$ indicate statistical significance at $1 \%$ and $5 \%$, respectively.

TABLE A4

Eight countries: descriptive statistics, 1994-2007

\begin{tabular}{llll}
\hline Country & dll & dllwage & 0.538 \\
\hline Argentina & 0.026 & 0.024 & 0.519 \\
Brazil & 0.027 & 0.044 & 0.308 \\
& 0.016 & 0.021 & 0.48 \\
Chile & 0.02 & 0.016 & 0.462 \\
& 0.014 & 0.024 & 0.519 \\
Colombia & 0.015 & 0.022 & 0.385 \\
Costa Rica & 0.027 & 0.014 & 0.506 \\
Mexico & 0.02 & 0.039 & 0.462 \\
Peru & 0.036 & 0.032 & 0.519 \\
Venezuela (Bol. Rep. of) & 0.025 & 0.036 & 0.385 \\
Average & 0.02 & 0.026 & 0.506 \\
& 0.013 & 0.025 & 0.385 \\
Source: & 0.03 & 0.032 & 0.506 \\
& 0.008 & 0.046 & 0.538 \\
\end{tabular}

Source: prepared by the author.

N.B.: For each country, the first row shows the mean of each variable and the second its standard deviation. rec is a dummy obtained from Gutiérrez (2007) which takes the value 1 when the country is in a phase of gdp slowdown.

(Original: Spanish) 


\section{Bibliography}

Agénor, P. and P. Montiel (1996), Development Macroeconomics, Princeton, Princeton University Press.

Alfaro, R. and others (2004), "The bank lending channel in Chile", Bank Market Structure and Monetary Policy, L. Ahumada and J.R. Fuentes (eds.), Santiago, Chile, Central Bank of Chile.

Anderson, P. (1993), "Linear adjustment costs and seasonal labor demand: evidence from retail trade firms", Quarterly Journal of Economics, vol. 108, No. 4, Cambridge, Massachusetts, The MIT Press.

Arellano, M. and S. Bond (1991), "Some tests of specification for panel data: Monte Carlo evidence and an application to employment equations", Review of Economic Studies, vol. 58, No. 2, Oxford, Blackwell Publishing.

Blanchard, O. and N. Kiyotaki (1987), "Monopolistic competition and the effects of aggregate demand", American Economic Review, vol. 77, No. 4, Nashville, Tennessee, American Economic Association.

Bond, S. (2002), "Dynamic panel data models: a guide to microdata methods and practice", CEMMAP Working Paper, No. CWP09/02, London, Centre for Microdata Methods and Practice.

Brock, P. and H. Franken (2003), "Sobre los determinantes de los spreads marginal y promedio de las tasas de interés bancarias: Chile 1994-2001", Economía chilena, vol. 6, No. 3, Santiago, Chile, Central Bank of Chile.

Bruno, G., A. Falzoni and R. Helg (2004), "Measuring the effect of globalization on labor demand elasticity: an empirical application to OECD Countries", CESPRI Working Paper, No. 153, Milan, Centre for Research on Innovation and Internationalisation.

Campa, J. and L. Goldberg (2001), "Employment versus wage adjustment and the U.S. dollar", Review of Economics and Statistics, vol. 83, No. 3, Cambridge, Massachusetts, The MIT Press.

Castro, L. and D. Saslavsky (2008), "Trade with China and India and manufacturing labor demand in Argentina”, UNU WIDER Research Paper, No. RP2008/108, Helsinki, World Institute for Development Economic Research.

Cavallo, M. and others (2005), "Exchange rate overshooting and the costs of floating", Working Paper Series, No. 2005-07, San Francisco, Federal Reserve Bank of San Francisco.

ECLAC/ILO (Economic Commission for Latin America and the Caribbean/International Labour Organization) (2009), "Crisis and the labour market", ECLAClILO Bulletin, No. 1, Santiago, Chile.

Edmond, C. and L. Veldkamp (2008), "Income dispersion and counter-cyclical markups”, NBER Working Paper, No. 14452, Cambridge, Massachusetts, National Bureau of Economic Research.

Fajnzylber, P. and W. Maloney (2004), "Labor demand and trade reform in Latin America", Journal of International Economics, vol. 66, No. 2, Amsterdam, Elsevier.

Galindo, A., A. Izquierdo and J. Montero (2007), "Real exchange rates, dollarization and industrial employment in Latin America", Emerging Markets Review, vol. 8, No. 4, Amsterdam, Elsevier.
Goldberg, L. and J. Tracy (2003), "Exchange rates and wages", NBER Working Paper, No. 8137, Cambridge, Massachusetts, National Bureau of Economic Research.

Gutiérrez, M. (2007), "Economic growth in Latin America and the Caribbean: growth transitions rather than steady states", Macroeconomía del desarrollo series, No. 58 (LC/L.2784-P), Santiago, Chile, Economic Commission for Lain America and the Caribbean (ECLAC). United Nations publication, Sales No. E.07.II.G.117.

Hahn, J., J. Hausman and G. Kuersteiner (2007), "Long difference instrumental variables estimation for dynamic panel models with fixed effects", Journal of Econometrics, vol. 140, No. 2, Amsterdam, Elsevier.

Haltiwanger, J. and others (2004), "Effects of tariffs and real exchange rates on job reallocation: evidence from Latin America”, Journal of Policy Reform, vol. 7, No. 4, London, Taylor \& Francis.

Hamermesh, D. (2004), "Labor demand in Latin America and the Caribbean: what does it tell us?", Law and Employment: Lessons from Latin America and the Caribbean, J.J. Heckman and C. Pagés (eds.), Chicago, The University of Chicago Press.

(1993), Labor Demand, Princeton, Princeton University Press.

Huang, R. and J. Ritter (2009), "Testing theories of capital structure and estimating the speed of adjustment", Journal of Financial and Quantitative Analysis, vol. 44, No. 2, Cambridge, Cambridge University Press.

IDB (Inter-American Development Bank) (2003), Good Jobs Wanted, Washington, D.C.

Loayza, N. and J. Rigolini (2006), "Informality, trends and cycles", Policy Research Working Paper Series, No. 4078, Washington, D.C., World Bank.

Maloney, W. and M. Bosch (2008), "Cyclical movements in unemployment and informality in developing countries", Policy Research Working Paper, No. 4648, Washington, D.C., World Bank.

Márquez, G. and C. Pagés (1998), "Trade and employment: evidence from Latin America and the Caribbean", RES Working Paper, No. 4108, Washington, D.C., InterAmerican Development Bank.

Mishra, P. and A. Spilimbergo (2009), "Exchange rates and wages in an integrated world", IMF Working Paper, No. 09/44, Washington, D.C., International Monetary Fund.

Peres, W. and B. Stallings (2000), Crecimiento, empleo y equidad: el impacto de las reformas económicas en América Latina $y$ el Caribe, Santiago, Chile, Economic Commission for Latin America and the Caribbean (ECLAC)/Fondo de Cultura Económica.

Rodrik, D. (1997), Has Globalisation Gone Too Far?, Washington, D.C., Institute for International Economics.

Vergara, S. (2005), "The dynamic of employment in Chilean industry", CEPAL Review, No. 86 (LC/G.2282-P), Santiago, Chile, August.

Weller, J. (2005), "Problemas de empleo, tendencias subregionales y políticas para mejorar la inserción laboral”, Macroeconomía 
del desarrollo series, No. 40 (LC/L.2409-P), Santiago, Chile, Economic Commission for Latin America and the Caribbean (ECLAC). United Nations publication, Sales No. S.05.II.G.195.
(2000), Reformas económicas, crecimiento y empleo. Los mercados de trabajo en América Latina y el Caribe, Santiago, Chile, Economic Commission for Latin America and the Caribbean (ECLAC)/Fondo de Cultura Económica. 